also the donor of two Chinese paintings on silk, a makimono and a sketch-book by Hokusai, another Japanese sketch-book, two Persian miniatures and a Coptic iron cross.

The Oriental Department also received some notable examples of Chinese ceramic art made specially for export, among these a porcelain bowl made for the Siamese market, given by Prof. Ellis H. Minns, of Pembroke College, and from the Hon. Lady Darwin another porcelain bowl which had been made for the European market, while an unusual punch bowl, intended for the same destination, was bequeathed by the late Lieut.-Colonel K. Dingwall. A Kutahia cup was a donation from Prof. Percy E. Newberry. In the Greek and Roman Department the most important acquisition was a fine south Italian bronze cinerary urn of the late sixth century B.c., purchased at the W. R. Hearst sale out of the Greek Antiquities Fund. Miss Winifred Lamb, honorary keeper of the Department, presented a Falisean skyphos of the fifth or fourth century B.c.

\section{British Museum Library Extension}

THE 'Iron Library' extension, which is now being completed at the British Museum, London, by H.M. Office of Works, is an interesting development in the introduction of welded steel work. The present structure is in the nature of an innovation, as it is the first example of an all-welded structural frame to be adopted by the Office of Works. The main factors influencing this decision were the greater neatness of the welded joint and the saving in headroom which it permits. It was designed to augment the bookshelf capacity of the Library. The extension occupies the north-east quadrant of the rectangular plot surrounding the historic Circular Reading Room and replaces a part of the existing structure of wrought iron and timber. In Electric Welding of May 1940, published quarterly by the Quasi-Arc Co., Ltd., of Bilston, Staffs., an instructive technical description, with photographs, is given of the building during the process of construction. Messrs. Dorman Long and Co., Ltd., are the constructors for the structural steel-work. They prepared and rolled the special sections; more than 500 tons of steel-work were necessary. Each welded joint was made in three runs from a No. 10 gauge electrode. The total number of welds in the structure exceeds 60,000 . The welding has been carried out with a maximum of ten operators, who between them have used about 47,000 quasi-arc electrodes. The necessary welding current was drawn from quasi-are Diesel, petrol and transformer units.

\section{Meteorology in Southern Rhodesia}

THE meteorological report for Southern Rhodesia for the year ended June 30, 1939, by R. A. Jubb, acting chief meteorologist, is dated January 1940 , but follows the general lines of those of pre-War years. Seasonal forecasts of rainfall of the type made by Sir Gilbert Walker, based on past departures from normal of meteorological elements $n$ selected action centres in other parts of the world, were continued, and were very successful in this year. The average rainfall over Southern Rhodesia during those months that correspond roughly with the winter of 1938-39 in the northern hemisphere, that is, Southern Rhodesia's summer rainfall of 1938-39, was forecast as 11.8 in. above normal ; actually it proved to be $12 \cdot 2$ in. above normal. This was the third year in succession during which the method was strikingly successful, and it is easy to believe that, as stated in the report, the forecasts are being found to be of practical value; there appears to be no sign that the correlation coefficients on which the forecasts are based are becoming smaller, as is sometimes the case after a considerable number of years of high correlation, for the least successful forecasting period of three years ended four years earlier. In Southern Rhodesia rain is of paramount interest, and it is satisfactory to note that whereas thirteen observing stations closed down, the number of new stations was forty-one.

\section{Map of the Karakoram}

A NEW map of the Karakoram has been published by the Royal Geographical Society (7s. 6d. or R. 5). Produced under the direction of Prof. K. Mason, it incorporates all published results of exploratory work up to Mr. E. Shipton's expedition of 1937. The scale is 1 to 750,000 and the size of the sheet is about twenty by twenty-three inches. The great altitude range from about $3,000 \mathrm{ft}$. to $28,000 \mathrm{ft}$. presented a difficult problem in representing relief. The layer colour system had to be abandoned. The contours in a region of such high relief are too close and the tint of the layer merged into the colour of the contour line. Moreover a satisfactory scheme of colour could not be found. Hill slopes are shaded with brown and purple on a general ground tint of yellow and generally the shading is cast from the north-west, but the direction varies slightly to suit the slope of the ground. Blue shading is used for snow and glaciers are white. Valleys have a layer tint of greyish-green. There are altogether eight colours and the map is a most effective piece of work. Heights are given in feet and the names employed are those decided on by the Karakoram Conference of 1937 and approved by the SurveyorGeneral of India.

\section{Metal Water-Jet Pump}

Aцтнолgh metal filter-pumps have been in common use for some time, the majority were imported. A new model developed and produced in Great Britain is now available. Metal filter-pumps are unbreakable and easily cleaned. In addition, the jet of the new model has been re-designed so that a high pumping speed can be reached even with pressures as low as $15 \mathrm{lb}$. in the water supply. Under suitable conditions, pressures of $15 \mathrm{~mm}$. or less of mercury are reached. The new pump should therefore prove of great service in general laboratory work involving distillations, filtrations or aerations and in hospital and surgical work. The pump and further details can be obtained from Messrs. W. Edwards and Co., Ltd., Southwell Road, London, S.E.5. 